\title{
Sinemanın Dijitalleşmesiyle Yönetmenin Kendini Görünmez Kılma Çabası: Abbas Kiarostami Örneği
}

\author{
Mehmet Emre Gül*
}

\section{Özet}

Sinemanın dijitalleşmesi yönetmenlere yapım ve yönetim açısından çeşitli imkanlar ve tercihler sunmaktadır. Dijital sinema kavramı; ilk olarak, bilgisayar ortamında oluşturulan, günlük yaşamda kaydedilmesi mümkün olmayan yapay görselleri içeren çağrışımlar yapsa da bundan daha fazlasını kapsamaktadır. Ticari/popüler sinema yapan yönetmenlerinve yapım şirketlerinin daha fazla yararlandığı düşünülen dijital sinemanın olanaklarından, sinemayı sanat olarak gören, hikaye anlatımına yeni bir boyut kazandırarak sinemayla felsefi kavramları tartışmaya açan ve sinemayı gerçekliğe daha çok yakınlaştırma amacındaki bağımsız ve minimalist yönetmenler de önemli ölçüde faydalanmaktadır. Bu çalışmada İranlı yönetmen Abbas Kiarostami'nin dijital sinemanın olanaklarını kullanarak eserin içinde kendini nasıl gizlediği ve yönetmenin değişen rollerini tartışılmaktır. Nitel araştırma tekniklerinden durum çalışması yöntemiyle Kiarostami'nin filmlerinde dijital sinema teknolojisinin imkanlarnı kullanma tarzına, filminde rol verdiği oyuncularla ve izleyicileriyle kurduğu iletişime 2002 yapımı Ten (10) ve 2008 yapımı Şirin filmleri üzerinden bakılacaktır. Dijital sinema teknolojisini oldukça özgün bir şekilde kullanan Abbas Kiarostami'nin Ten ve Şirin filmleri de hikaye, oyunculuk, görüntü düzenlemesi/çerçeveleme, kurgu teknikleri ve filmde kullanılan mekanlar bă̆lamında incelenecektir.

Anahtar Kelimeler: Dijtal Sinema, İran Sineması, Abbas Kiarostami, Ten, Şirin

ORCID ID : 0000-0002-5916-9949

E-mail : mehemgul@gmail.com

DOI: $10.31122 /$ sinefilozofi.513304

Geliş Tarihi - Recieved: 20.01.2019

Kabul Tarihi - Accepted: 02.04.2019 


\title{
Director's Attempt to Make Himself Invisible with the Digitalization of Cinema: A Case Study of Abbas Kiarostami
}

\author{
Mehmet Emre Gül*
}

\begin{abstract}
Digitalization of cinema provides directors various possibilities and preferences in terms of production and direction. The concept of digital cinema involves more than just the connotations created in the computer environment, which contain artificial images that cannot be recorded in everyday life. It is thought that only commercial / popular cinema directors and producer companies benefit more from the characteristics of digital cinema. However independent and minimalist directors, who regard cinema as an art, introduce a new dimension to storytelling and discuss philosophical concepts with cinema and aim to bring cinema closer to reality also benefit from the possibilities of digital cinema significantly. This paper discusses how Iranian director Abbas Kiarostami conceals himself in his own films by using the possibilities of digital cinema and the changing roles of the director. With case study method, the use style of digital cinema technology his communication with his actors and audiences in Kiarostami's films will be analysed through Ten (2002) and Shirin (2008) film examples. These two films will be examined in the context of story, acting, image editing / framing, editing techniques and the places used in the film.
\end{abstract}

Anahtar Kelimeler: Digital Cinema, Iranian Cinema, Abbas Kiarostami, Ten, Shirin

ORCID ID : 0000-0002-5916-9949

E-mail : mehemgul@gmail.com

DOI: 10.31122/sinefilozofi.513304

Recieved - Geliş Tarihi: 20.01.2019

Accepted - Kabul Tarihi: 02.04.2019 


\section{Giriş}

"Filmlerimin bazılarında yönetmen olarak ne yaptığım sorulacak olsa 'Hiçbir şey. Ama yine de ben olmadan var olamazlardı' derim."

Abbas Kiarostami, 2017: 191

Sinema her şeyden önce teknolojik gelişmelerin sonucunda ortaya çıkmış bir sanat dalıdır ve teknolojiyle iç içedir. Sinema teknolojisinin gelişmesi sinemanın teknik, içerik ve biçem boyutlarını da etkilemiştir. Filmlerin sürelerinin uzaması, sesin sinemaya gelmesi, filmlerin renklenmesi, objektiflerin çeşitlenmesi gibi teknolojik gelişmeler sinemayı sadece teknik açıdan kusursuzlaştırmakla kalmamış, sinemanın kendine has bir dil geliştirmesini sağlamıştır. Bu bahsettiğimiz teknolojik gelişmeler filmle yani pelikülle ilgili gelişmelerdi. $\mathrm{O}$ dönemde film yapmak aynı zamanda kimyasal bir işlemdi. Fakat 1980'li yıllardan itibaren sinemada yeni bir teknolojik devrim yaşanmıştır. Buna dijitalleşme de diyebiliriz. Bu durum birçok sinemacı ve kuramc1 için "sinemanın ölümü" olarak düşünülüp bu döneme "dijital karanlık çağ" ismiyle anılsa da ölen sinema değil yalnızca peliküldür(Erkılıç,2017). Dijital sinema; sanal gerçeklik veya görsel/işitsel efektler gibi yenilikler sunmuş ve sinema endüstrisine yeni bir soluk getirmiştir. Sinema endüstrisi, bu yenilikleri kullanarak sanal ortamlarda filmler üretmişlerdir fakat dijital sinema sadece bu filmlerden ibaret değildir. Sinema endüstrisiyle doğrudan ilişki kurmayan, bağımsız ve sanatsal kaygıyı ön planda tutan yönetmenler de dijital sinema teknolojilerine kayıtsız kalmamış, bu teknolojilerden faydalanmışlardır. “Dijital sinemada sınırsız seçme özgürlüğüne kavuşmuş olan sanatçı diğer yandan gerçekliğin karşı çıkılamayacak bir yeniden yaratımını ortaya çıkarma şansına kavuşmuştur" (Ormanlı, 2012: 34). Dijital sinema, yönetmenin varlığını filmin içinde -görsel efektler, kurgusal geçişler vb. yollarla- ihtişamlı bir şekilde izleyiciye gösterebildiği gibi yönetmenin kendi varlığını mütevazı bir biçimde gizlemesine de olanak sağlamaktadır. Yönetmen-oyuncu-seyirci ilişkisindeki sınırlar dijital çağda gittikçe saydamlaşmıştır. Bu çalışmanın temel problemi Abbas Kiarostami'nin dijital sinema teknolojisinin olanaklarını kullanarak kendisini filmlerinin içinde nasıl görünmez kıldığ1 sorusuna cevap aramaktır. 'Yönetmenin kendini eserinde gizlemesi' veya yönetmenin eserin içinde kaybolması vb. ifadeler yerine 'görünmezlik' bilinçli olarak tercih edilmiştir. Bunun sebebi, görünmez olanın gözle görülmese bile varlığının bilinmesi ve hissedilir olmasıdır. Hem film setindeki oyuncular açısından hem de izleyiciler açısından bakıldığında Kiarostami' nin durumunu karşılamak için en uygun terim 'görünmezlik'tir. Kiarostami'nin kendini görünmez kılma çabasının araştırılma nedeni ise sadece filmlerine bakılarak yapılan bir varsayım değil; yönetmenin birçok röportajında böyle bir niyeti olduğunu ifade etmesidir.

\section{Çalışmanın Metodolojisi}

Bu çalışmada ilk olarak sinema teknolojisinin tarihsel gelişimine, daha sonra da dijital sinemanın sağladığı olanaklara yer verilmiştir. Sinema filmlerinin üretildikleri ortamın, kültürel, politik ve toplumsal koşullardan etkilendiği de göz önünde bulundurularak (Kirel, 2007:375), İran sinemasının temel dinamikleri saptandıktan sonra Abbas Kiarostami sinemasının özelliklerine ve dijital sinemayla kurduğu ilişkiye bakılmıştır. Kiarostami, röportajlarında zaman zaman 'kendini görünmez kılma' isteğinde olduğunu ve bunun için de dijital teknolojilerin büyük avantajlar sağladığını ifade etmektedir. Çalışmada, Kiarostami'nin bu söylemlerinden hareketle eserlerinde kendini görünmez kılmasının mümkün olup olmadığ1 
araştırılmaktadır. Çalışmada sağladığı güçlü veri arşivi ile yapılacak birçok araştırma için veri kaynağı teşkil eden nitel araştırma yöntemlerinden durum çalışmasıdır (Aytaçlı, 2012). Durum çalışması yapılırken veri olarak; Kiarostami'nin yaşamöyküsü, içinde bulunduğu üretim koşulları, yönettiği filmler ve kendisiyle yapılan röportajlar kullanılmıştır. Veriler toplanırken; dijital sinema, İran Sineması ve Abbas Kiarostami sineması üzerine literatür taraması yapılmış, yönetmenin çeşitli kitaplarda, internet sitelerinde ve dergilerde yapılan röportajları incelenmiş, Kiarostami' nin teknolojinin olanaklarından faydalanarak eserlerinde kendini nasıl görünmez kıldığ1 tartışılmış ve seçilen filmleri analiz edilmiştir. Kiarostami' nin filmografisine bakıldığında oldukça üretken bir yönetmen olduğu görülmektedir. Kiarostami; kısa film, belgesel ve orta metrajlı filmlerin haricinde on bir adet uzun metrajlı film ${ }^{1}$ yönetmiştir. Bu on bir uzun metrajlı filmin dokuzu $35 \mathrm{~mm}$ ile kaydedilirken ikisi ise dijital formatta kaydedilmiştir. $\mathrm{Bu}$ veriden yola çıkarak, çalışmanın örneklemini dijital film teknolojisini kullanarak yapılan Ten (On, 2002) ve Shirin (Şirin, 2008) filmleri ile Kiarostami'nin dijital teknoloji ve yönetmenin değişen rolleri üzerine tasnif edilen röportajları oluşturmaktadır. Araştırmanın örneklemini oluşturan iki film; hikâye, oyunculuk, görüntü düzenlemesi/çerçeveleme, kurgu teknikleri ve filmlerdeki mekân kullanımı açılarından analiz edilmiş, yapılan analiz Kiarostami'nin röportajlarında ifade ettiği görüşleriyle desteklenmiştir.

\section{Analogdan Dijitale Sinemanın Teknik Tarihi}

Tarihsel bir süreç olarak ele alındığında kamera gibi ‘büyülü’ bir aleti icat etme çabaları Leonardo da Vinci'nin Camera Obscura'sına kadar gider. Fotoğrafın icadından sonraki süreçte ise hareketli görüntünün kökenlerini 1798 yılında Etienne Gaspard Robertson'un Phantasmagoria's1, Robertson'u 1890'lı y1llarda ise Edison'un 1891'deki Kinetoscope'u, 1892' deki Emile Reynaud'nun Pantomimes lumineuses'i ve bundan yaklaşık üç yıl sonra sinemanın doğumu olarak kabul edilen Lumiere Kardeşlerin Sinematograf icadı izler. Hareketli görüntüyü kaydetme denemeleri sinemayı icat etmek için yapılmamıştı. Asıl amaç hareketin doğasını anlamak ve hareketi yeniden üretebilmekti. Hareketli görüntüler ham film şeritlerine kaydediliyordu. Şeritlerin genişliği içinse farklı kişiler ve şirketler $8 \mathrm{~mm}, 9.5$ mm, $15 \mathrm{~mm}, 16 \mathrm{~mm}, 17.5 \mathrm{~mm}, 22 \mathrm{~mm}, 28 \mathrm{~mm}, 35 \mathrm{~mm}, 45 \mathrm{~mm}, 60 \mathrm{~mm}, 63 \mathrm{~mm}$, birçok farklı ölçü piyasaya sürülmüştür. Fakat bunlardan en yaygını profesyoneller için Edison'nun icadı Kinetoscope'la uyumlu olan $35 \mathrm{~mm}$ ve Kodak'ın amatörler için tasarladığ $16 \mathrm{~mm}$ olmuştur. 1895'den 1920'lerin sonuna yani sesin gelişine kadar kameralar için standart ölçü saniyede 16 kare kaydedilmiştir. Bu durum ses bandının film şeridine dahil olması sonucunda belirli bir senkron yakalanabilmesi için saniyede 24 kare olarak devam etmiştir. Ses bandının film şeridine dahil edilmesi sinemanın icadıyla birlikte gerçekleşmese de sinemanın ilk yıllarından itibaren düşlenmekteydi. Sinemaya sesin gelişi 1927 yılında Alan Crosland'in yönettiği Warner Bros. şirketinin yapımcılığını üstlendiği Caz Şarkıcısı olarak kabul edilse de Fransız Eugene-Auguste Lauste 1906 yılında sesi doğrudan film şeridine kaydetmeyi başarmıştır. Birinci Dünya Savaşı' ndan sonra Almanya' da Vogt, Engel ve Massolle sesleri TriErgon sistemi adı verilen ışık biçimine çevirip farklı bir şeride kaydederek 1922' de Berlin'de bir gösterim gerçekleşmiştir. Warner Bros'un bu ticari hamlesine Fox ise TriErgon ve Photophone' un patent hakların satın alarak karşılık vermiştir. Bu gelişmeleri Movietone'nun icadı izlemiş ve bu sistemin daha

1 Mossafer (Yolcu, 1974), Khane-ye doust kodjast? (Arkadaşımın Evi Nerede?, 1987), Nema-ye Nazdik, (Yakın Plan, 1990), Zendegi va digar hich (Ve Yaşam Sürüyor..., 1992), Zire darakhatan zeyton (Zeytin Ağaçları Altında, 1994), Ta'm e guilass (Kirazın Tadı, 1997), Bad ma ra khahad bord (Rüzgar Bizi Sürükleyecek, 1999), Ten (On, 2002), Shirin (Şirin, 2008), Copie conforme (Aslı Gibidir, 2010), Like Someone in Love (Sevmek Gibi, 2012). 
pratik olması nedeniyle yaygın olarak kullanılmaya başlandı ve sese geçişin temeli oldu (Usai, 2008: 22-27). 1970'lere gelindiğinde ise ses sistemi dijitalleşti. Tıpkı sesi sinemaya dahil etmekte olduğu gibi sinemacıların sinemanın ilk yıllarından itibaren bir başka uğraşı da siyah beyaz görüntüyü renklendirmek olmuştur. 1900-1935 yılları arasında birçok renk sistemi ortaya çıkıp bazıları belirli ölçüde başarılı olsa da belirli bir standart yakalanamamıştır. 1920'lerde Eastman'ın geliştirdiği Sonochrome belirli ölçüde renkli görüntü sağlasa da en önemli gelişme 1935 yılında Techicolor'un geliştirdiği üç-kuşak işlemidir. Bu sistemde magenta (kırmızı), cyan (mavi) ve yellow (sarı) renkler temel alınıyordu. 1952 yılında ise Eastman Kodak yeni bir renkli negatif üretti ve sinema endüstrisi tarafından oldukça talep gördü (Monaco, 2014: 116-117). Sinemanın bir başka önemli teknik aşaması kurgu ise 1920'lere kadar ilkel tekniklerle yapılıyordu. Filmde kullanılmasına karar verilen ham filmler bir makasla kesilip yapıştırıcılarla yeniden birleştiriliyordu. Pelikül üretiminin kolaylaşması ve film sürelerinin uzamasıyla bu işlem gittikçe karmaşık bir hal almaya başladı ve 1920'lerde Almanya'daki UFA stüdyoları'nda düz yataklı bir kurgu masası geliştirildi ve İkinci Dünya Savaşı'na kadar yaygın olarak kullanıldı. Amerika' da ise yine aynı yıllarda geliştirilen Moviola isimli bir kurgu makinesi tasarlandı ve bu cihaz 1960'ların ortalarına kadar kullanıldı. 1970'lerden itibaren ise CBS ilk kez bilgisayarlı kurguyu piyasaya sürdü ve bunun ücreti 1 milyon dolardı. 1980'lerde ise çok daha ucuz ve kişisel bilgisayarlarla bile uyumlu çalışan Avid kurgu programlarıyla kurgu anlayışı yeniden şekillenmiştir (Monaco, 2014: 128). Günümüzde ise Final Cut, Edius, Adobe Premiere gibi profesyonel sinemacılar tarafından kullanılan birçok kurgu programı ve bunun yanında amatör sinemacılar için birçok ücretsiz kurgu yazılımı mevcuttur.

Bahsedilen bütün bu teknik gelişmeler sinema dilini de bir biçimde etkilemiştir. Pelikülün yaygınlaşması ve arka arkaya eklenmesiyle film süreleri uzamış, bu da doğal olarak daha uzun hikayeler anlatma olanağı sağlamıştır. Sinemaya sesin gelmesiyle de filmlere diyalog eklenmiş ve çevresel sesler girmiş, bu durum da filmlerin içeriklerinde köklü değişimlere neden olmuştur. Hareketli görüntünün kaydedilmesi, sesin sinemaya gelmesi gibi önemli teknik gelişimleri 1940'larda denenmeye başlayan ve 1980'lerde yaygınlaşan dijitalleşme izlemiştir. Bu döneme kadar olan süreci Fener (2012: 11), Film (Pelikül) Çağı olarak adlandırmıştır. Bundan sonraki dönemi ise dijital çağ olarak adlandırmak mümkündür. Film çağında görüntü kaydetme işlemi fiziksel (optik) bir süreçken montaj kimyasal bir işlemdir. Filmlerin kaydedilmesi, yıkanması, kurgulanması gibi aşamaları büyük bir titizlik ve çaba gerektirmekteydi. Bu işlemler için uzmanlık ve iş bölümüne ihtiyaç vardı. Dijital çağda ise her şeyin sanal ortamda yapılması ile bu işlemler hem daha az kişi tarafından yapılabilmekte hem de eskisine nazaran daha az uzmanlığa ihtiyaç duyulmakta. Parsa ve Akçora (2016), film üretiminde uzun yıllar boyunca vazgeçilmez olan pelikül üretim, dağıtım ve gösteriminin sona erdiğini ve pelikülün sonlanmasıyla dijital sinemanın yeni bir kavram olarak literatüre girdiğini ifade etmektedir.

Erkılıç (2017: 68), pelikülün yirminci yüzyıla, dijital görüntünün ise yirmi birinci yüzyıla ait olduğunu ifade eder. "Pelikül geçmiş, dijital ise gelecek demektir. Pelikül belleğimiz, tarihimiz olurken, dijital gelecek yeni fırsatlarımızı ima etmektedir. Dijital teknoloji her gün bir önceki teknolojik gelişimi bir daha hiç kullanılmayacakmış gibi yok etmekte, sürekli değişerek yeni olanaklar ve fırsatlar sunmaktadır.". "Her dönüşüm süreci, sancılı ve belirsizlikler içinde ancak yaratıcı fırsatlara da olanaklar tanıyarak gelişir. Sinemadaki dijital dönüşüm, günümüz yaratıcıları için yeni keşifler vaat etmektedir". 


\section{Dijital Sinemanın Dönüşümü ve Sağladığı Olanaklar}

Mehmet Köprü (2009:57), dijitalleşmenin filmler üzerindeki etkisini “yapım koşullarıyla ilgili değişimler (estetik ve biçimsel boyut), dağıtım ve ulaşımdaki değişimler (endüstriyel ve ekonomik boyut), seyir deneyimlerindeki ve seyirci alımlamasındaki değişimler (kültürel, sosyal ve psikanalitik boyut)" olmak üzere üç başlıkta ele almıştır. Bu başlıkta daha çok 'yapım koşullarıyla ilgili değişimler' üzerinde durulacaktır. Sinemanın dijitalleşmesiyle yönetmenler analog dönemle kıyaslandığında daha geniş bir özgürlük alanına sahip olmuştur. Teknik olarak bakıldığında görüntü kaydetme, ses kaydetme ve kurgu sistemleri olarak üç ana başlıkta incelendiğinde dijitalleşmenin film yapım yöntemlerinde de köklü değişikliklere yol açtığı görülmektedir.

Bunları tek tek ele almak gerekirse; kameranın dijitalleşmesiyle ilk olarak maliyeti yüksek olan ham film yerini hafıza kartlarına bırakmış ve yönetmenlerin/yapımcıların üstündeki ekonomik baskılar bir nebze de olsa hafiflemiştir. Aynı zamanda kameraların ucuzlaması da ona sahip olma imkanını kolaylaştırmış, böylece sinema belirli grupların tekeline mahkum kalmamıştır. "Dijital sinema kameralarıyla çalışmak çekim aşamasında görüldüğü gibi farklı anlatım tarzlarını oluşturmada kolaylıklar sağlamaktadır. Bunun yanı sıra kasetlerin fiyatları asla ham film kadar maliyetli değilken yeni teknolojide harddiskler ve kartlar tekrar tekrar kullanılabilmektedir Dijital sinemada sınırsız seçme özgürlüğüne kavuşmuş olan sanatçı diğer yandan gerçekliğin karşı çıkılamayacak bir yeniden yaratımını ortaya çıkarma şansına kavuşmuştur." (Ormanl1, 2012: 34) Bir diğer önemli gelişme de kamera kullanmanın eskisine göre daha az uzmanlık ve beceri gerektirmesidir. Bunlara ek olarak bir de kameraların boyut olarak küçülmesi de hem taşınmasını kolaylaştırmış hem de oyuncuları rahatlatmıştır. Kiarostami, video kameraların sundukları özgürlük sayesinde film yapımcılarını sinemanın kökenlerine götürdügünü, tek bir ekipman ve oyuncu ile artık -neredeyse- hiçbir kaynağa ihtiyaç duymadan film çekilebileceğini ifade eder (Cronin,2017: 45).

Ses kaydının dijitalleşmesi de kameranınkine benzer bir şekilde gerçekleşmiştir. Analog dönemde manyetik bantlara yapılan kayıtları yapmak oldukça güç bir işlemdi. Birçok film yapımcısı ve yönetmen sesleri sette kaydetme şansına bile sahip değildi. Filmler baştan sona sessiz çekilip daha sonra stüdyolarda oyuncular tarafından tekrar seslendiriliyordu. Doğal sesler de aynı şekilde stüdyoda foley ile oluşturuluyordu. Dijital ses kayıt cihazlarının dijitalleşmesiyle cihazlar küçüldü ve maliyetleri, seslerin işlenmesi vs. kolaylaştı. Bunların sonucunda filmin seslerini canlı şekilde yani sette kaydetmek yaygınlaştı ve bu da film yapımcılarının/yönetmenlerin işini büyük oranda kolaylaştırdı.

Kurgu sistemlerinin dijitalleşmesi de kaydedilen görüntülerin ve seslerin işlenmesini ve birleştirilmesini analog döneme göre ciddi ölçüde kolaylaştırmıştır. "1970'lerde kurgu bilgisayar ortamına adapte edilmeye çalışılmış, başarıya ise 1990'larda ulaşılmıştır. 2000'li yıllar Hollywood da dâhil olmak üzere pek çok sinema kurgu yapımını dijital ortama taşıdı" (Nişancı, 2011: 67-68). Ham film şeritlerinin izlenmesi ve filmin akışına uygun şekilde birleştirilmesi oldukça meşakkatli bir işlemdir. Analog dönemde kurgu yapmak sadece zihinsel beceri değil aynı zamanda el becerisi de istemektedir. Çünkü kurgu günümüzde olduğu gibi sanal değil somuttur. Yapılan bir yanlış birleştirme işlemini geri almak bilgisayarda olduğu kadar kolay değildir. Bunların yanında dijital kurguda yönetmenlerin ve kurgucuların hatalarını görme ve düzeltme şansları artmıştır. Sesler ve görüntüleri senkronize etmek daha kolaylaşmış, filmlerin renklerini düzenlemekte seçenekler artmıştır. 
Bütün bunların dışında (kamera, ses, kurgu) dijitalleşme yeni bir alan daha açmıştır. Bu da sanal gerçekliktir. Sanal gerçeklik ise kısmen veya tamamen bilgisayar ortamında üretilen görüntü ve efektleri içerir. Yönetmenleri ve yapımcıları kameranın kaydettiği gerçekliğinin de dışına taşır. Sanal gerçekliğin sinemaya girişindeki milat ise John Lasseter'in yönetmenliğini üstlendiği Toy Story (Oyuncak Hikayesi, 1996) filmidir. Bu film sanal ortamda yapilan ilk uzun metrajlı filmdir. (Elsaesser ve Hagener, 2014: 304) Oyuncak Hikayesi filminden önce ise Jurassic Park (1993) Forrest Gump (1994) filmlerinde sanal ortamda oluşturulan görüntüler ile kamerada kaydedilen görüntüler bir arada kullanılmıştır. Bu filmleri Titanic (1997), Gladyatör (2000), Yüzüklerin Efendisi üçlemesi (2001-2003) ve Harry Potter serisi (2001-2011) gibi dijital teknolojilerden ciddi ölçüde faydalanıp ticari anlamda büyük başarı elde eden filmler izlemiştir (Bergan, 2008).

Sinemanın dijitalleşmesi sadece teknik konularda bir dönüşümle beraber dramaturjik açıdan da birtakım değişikliklere yol açmıştır. Yönetmenlerin film yapım yöntemleri ve oyuncu yönetimleri de bu yeni dijital araçların yapısına göre yeniden şekillenmiştir. Oyuncu/ yönetmen Mel Gibson dijital film ekipmanlarının değişme pratiklerini "İstediğim anda kameranın arkasından sete atlayarak oyuncularla beraber bir sahneyi çekip, seyredip sonra da nasıl olması gerektiğini tartışıyorduk. HD ile çalışmak size daha fazla alan bırakıyor, deneme yapıp, tartışma olanağı buluyorsunuz. Bu işleri çok pahalı film stokunu boşa harcama pahasına yapamazsınız." sözleriyle ifade ederken, hem yönetmenlik hem de oyunculuk yapan bir başka Amerikalı sinemacı Tony Bill ise Gibson'un sözleriyle benzer bir şekilde bu değişimi şu şekilde ifade etmiştir:

"100 yıllık bir dönem içinde oyuncular birçok teknik kısıtlamalarla boğuştular, çekimden önce prova yapmak zorundaydılar ve ancak 'aksiyon-kes' kelimeleri arasında kamera çalışırken oyunculuklarını sergileyebiliyorlardl, çalışan kamerada tüketilen film daima akullarının bir köşesinde onları rahatsız eden bir unsur olarak yer alı duruyordu. HD çekim bu gerilimi alıp götürüyor. Artık provaya gerek yok her şeyi istediğiniz şekilde çekebilirsiniz, doğaçlama yapmak artık çok kolay.' (Fener,2012: 18-19)

İki yönetmenin sözlerinin ortak noktası, sınırsız deneme imkânı, oyuncuların performanslarındaki artış ve düşen maliyetlerdir. Abbas Kiarostami ise 35 milimetrelik bir filmle yönetmenin her şeyi kontrol altına alması ve sürekli müdahelede bulunması gerektiğini belirtir. Dijital teknolojilerin ise yönetmen ve oyuncu arasındaki mesafeyi koruduğunu ve bu nedenle de oyuncuların daha doğal olabildiğini, bu durumun da kendisini "tıpkı yeni bir renk keşfeden ressam misali" heyecanlandırdığını ifade eder (Cronin, 2017: 42-43).

Film ekipmanlarının küçülmesi ve kontrolünün kolaylaşması da sinemacıların işini kolaylaştırmıştır. Bütün bu gelişmeler filmlerin maliyetini düşürmüş, tekrar çekim ve yeni denemelere olanak tanımış, çekilen görüntülerin korunmasını kolaylaştırmıştır. Sinemanın dijitalleşmesi genç veya pratik anlamda tecrübesiz sinemacıların düşük riskler alarak kendilerini denemesine fırsat sağlarken tecrübeli yönetmenlerin de yaratıcılıklarının önündeki engelleri kaldırmıştır. Dijtal sinema, geleceğe uzanan yolların temelini atmaktadır. Bundan sonraki süreçte her uzunlukta ve her türde filmin çekileceği, çekilen filmlerin farklı boyutlardaki ekranlarda gösterileceği bir döneme girilmiştir. (Elsaesser ve Hagener, (2014: 314) 


\section{İran Sineması'na Genel Bir Bakış}

Hamid Nafisi, İran Sineması'nı Sessiz Dönem (1900-1930), Sesli Dönem (1930-1960), Modern Dönem (1960-1978) ve Devrim Sonrası Dönem (1978-1994) olmak üzere dört dönemde incelemiştir. Sessiz Dönem yıllarında ağırlıklı olarak Kaçar kraliyet ailesinin finansal desteğiyle belgesel ve haber filmleri üretilmiştir. İlk uzun metrajlı film de Sessiz Dönemin sona ereceği 1930 yılında Ermeni asıllı İranlı Avanes Ohanyan'ın çektiği Abi ve Rabi filmidir. Sinemaya 1927 yılında sesin gelişinin ardından kısa bir süre sonra İran'da da 1930 yılında Amerikan üretimi sesli filmler gösterilmeye başlanmış ve İran ilk sesli filmini 1933 yılında çekilmiştir. 1940'larda yabancı filmlere gelen sansürün sonucunda İran film endüstrisi önemli ölçüde gelişim göstermiştir. 1960'tan 1978' deki İslami Devrim'e kadar süren Modern Dönem'de ise modernleşme sonucunda Batı' da eğitim alan sinemacıların etkisi görülmektedir. Bu dönemin başlangıcı olarak 1960 gösterilse de dönemin ses getiren filmleri a Mesud Kimiya' nın yönettiği Kayser ve Deryuş Mehrcui' nin yönettiği Gav (İnek, 1969) filmleridir. Bu iki film ilerleyen yıllarda İran Yeni Dalgası olarak kabul edilecek bir hareketin öncüleri olarak da kabul edilmektedir Nafisi, (2008: 766). İran' da Modern Dönem 1978' de gerçekleşen İslami Devrim ile sona ermiş ve günümüzde de İran'da hala etkisini gösteren Devrim Sonrası Dönem başlamıştır. İran'da sinemanın tarihsel gelişimi, teknik ve içerik olarak dünya geneliyle büyük oranda paralel olarak ilerlemekteyken İslami Devrim İran Sineması için bir kırılma noktası olmuştur ve İran Sineması'nı toplumsal/politik/kültürel nedenlerle bambaşka bir noktaya taşımıştır. "Sinema filmlerinin üretildikleri ortamın kültürel, politik ve toplumsal koşullarından etkilendiği ortadadır." Bu dönemde İran'da film yapımının önündeki en büyük engel, devletin sansür uygulamasıdır.(Kırel, 2007: 375) Devrim Sonrası İran halkı ve yönetimleri tarafından bazı filmler ve yönetmenler 'tehlikeli' bulunup film üretimleri önüne engeller çıkarılsa da bazı 'muhalif' yönetmenler yaptıkları başarılı filmler sayesinde uluslararası festivaller tarafından önemsenmiş, desteklenmiş ve değer görmüştür. Bu dönemin önemli temsilcileri arasında devletin uyguladığı katı sansüre rağmen sanatsal tavırlarından taviz vermeyen ve söylemek istediklerini her şeye rağmen söyleyen Abbas Kiarostami, Behram Beyzayi, Perviz Kimyavi, Muhsin Mahmelbaf, Asghar Farhadi, Jafer Panahi gibi uluslararası seviyede birçok başarı kazanmış isimler gösterilebilir. Bu yönetmenlerin her birinin kendine ait farklı bir üslubu ve sinema dili olsa da belirli noktalarda benzeşmektedirler. Bu isimlerin benzeştiği noktaları saptamak için Kırel'in (2007:411) İran sinemasında dikkat çektiği birtakım karşıtlıklar bu yönetmenlerin ortak özelliklerinin ne olduğu noktasında önemli ipuçları vermektedir:

İran filmlerinin; özel alan-kamusal alan, kadın dünyası-erkek dünyası, yetişkin dünyası-çocuk dünyası, kent kültürü-kırsal kültür gibi birkaç temel çatışmaya dayandırldıklarn öne sürülebilir. Üretim koşullar göz önünde bulundurulduğunda ise bu filmlerin; küçük bütçeli yapım ya da ortak yapım mantığı ile üretildiği, sıradan insanı gerçekçi bir biçimde temsil ettikleri, profesyonel oyuncu yerine amatör oyuncu kullanımıyla dikkat çektikleri, gerçekçi yaklaşım özelliğine sahip oldukları, şiddet, cinsellik, müstehcenliğe yer vermedikleri, simgesel anlatımı kullandıkları, sıradan insanın yaşamına odaklandıklarn, politik, dini ve ekonomik sansürün etkisi ile üretildikleri, genellikle az sayıda oyuncuya sahip olduklarl, belgeci bir yaklaşımın izinde oldukları, İslam kültürüne ait gündelik değerleriyle alı̧kanlıklar gündeme getirdikleri ya da sorguladiklarn (görev, vicdan, sorumluluk gibi), bu kültüre ait kısıtlamalarn gündeme getirdikleri ya da sorguladıkları (kamusal alanda sıkışışlı, yasaklar, özel hayatın kısıtlanmışlığı, tensel aşkın konu edilmemesi vs. gibi). Sade bir anlatım dilini benimseyen bu yapımların daha çok 'auteur' sinemasına göz kırpan çalışmalar oldukları öne sürülebilir." 
Kırel' in ifadelerine bakıldığında İran filmlerinin düşük bütçeler, amatör oyuncu kullanımı, simgesel ve sade bir anlatım tercih eden belgeci bir yaklaşıma sahip olduğu görülür. $\mathrm{Bu}$ açıdan düşünüldüğünde minimalist bir sinema anlayışının varlığından söz edilebilir. "Minimalist sinemanın en önemli özelliği hikâye anlatımındaki bilge sadeliğiyle, kamerakullanımındakiekonomiktavır" dır.(Kıraç,2000:15) Minimal sinema genellikle imkanların yetersizliğinden ortaya çıkan bir eğilimin doğal bir sonucu olarak ortaya çıkmaktadır. İran sinemasında bunlara ek olarak devletin katı sansür politikası da yönetmenleri söylemek istediklerini minimal bir tarza yönlendirmektedir. "Sinema üretim koşullarındaki değişkenlerin filmleri doğrudan etkilediği düşünülürse bu özelliğin İran Sineması'nın diğer ülke sinemalarına göre en önemli farkını oluşturduğu söylenebilir. Bu yüzden, İranlı yönetmenlerin elini kolunu bağlayan sansür karşısında filmlerini çekerken yeni yöntemler geliştirdikleri görülmektedir" (Kırel, 2007: 375) Bu noktada yönetmenin tercihleri devreye girmektedir. Sansüre takılmamak için İran' daki rejimin ideolojisini destekleyip yüksek bütçelerle ve gelişmiş teknik imkanlarla çalışıp sanatsal yaklaşımından taviz vermekle düşük bütçelerle ve kısıtlı imkanlarla istediğini anlatmak arasında tercih yapması gerekmektedir. Analog dönemde sansür uygulamak belki de daha kolay olabilir; lakin dijital teknolojilerin yaygınlaşmasıyla üçüncü bir ihtimal daha doğmuştur. Kiarostami de bu üçüncü ihtimalin önemini kavramış ve bu teknolojinin imkanlarıyla sansür, bütçe gibi engelleri aşmıştır. Bunlara ek olarak bu dijital araçlar sayesinde belki de analog dönemde analog film ekipmanlarının hantallığı, yüksek maliyeti vb. nedenlerden kaynaklanan sorunlardan dolayı gerçekleşmesi güç olan bir doğallığa dijital teknolojiler sayesinde ulaşmıştır. Abbas Kiarostami sansür, ekonomik kısıtllık gibi engeller karşısında pes etmemiş ve görüşlerini anlatmanın bir yolunu daima bulmuştur. Kiarostami bu durumu kendine has şiirsel üslubuyla şu sözlerle açıklamaktadır: "Kuşlar, en çok kafeste tutulduklarında şakır". (Cronin, 2017: 19)

\section{Abbas Kiarostami Sinemas1}

1940 doğumlu Abbas Kiarostami, güzel sanatlar alanında eğitim görmüştür. Grafiker olarak çalıştıktan sonra kısa filmler çekmiştir ve ilk uzun metrajlı filmi Mosafirdir (Misafir, 1974). Kiarostami, sinemaya başladığı ilk yıllarda çocukların ve gençlerin yaşamını konu alan filmleriyle ünlenmiştir (Teksoy, 2014: 751). Uluslararası alanda tanınan bir yönetmen olması ise 'Köker Üçlemesi olarak bilinen Arkadaşımın Evi Nerede?, 1987), Ve Yaşam Sürüyor..., 1991 ve (Zeytin Ağaçlarının Altında, 1994) filmleridir. Yakın Plan, Kirazın Tadı, Rüzgar Bizi Sürükleyecek, Aslı Gibidir, Like Someone In Love (Sevmek Gibi, 2012) ise yönetmenin diğer önemli eserleridir. Kiarostami minimalist, şiirsel, felsefi, duygusal, sanatsal bir stile sahiptir. Kiarostami bir yönetmen olarak bütün filmlerinde sinemayı gündelik hayata yakınlaştırmış, buna rağmen felsefi ve sanatsal açıdan da güçlü eserler üretmiştir. Onun sinemasında minimalizm ve doğallık öne çıkmaktadır. "Kiarostami'nin, özenli çerçevelemelere dayanan, ağır akışlı, dingin ve yalın sineması insanın başkalarıyla iletişimin ve gerçekle sanal arasındaki ilişkiyi doğu kültürünün verileriyle çözümlemeye yönelik bir sinemadır." (Teksoy, 2014: 752). Dabashi (2013: 40) ise Kiarostami'nin sinemasını "dünyayı, sıradan bakış açısından gizlenen, biraz daha tuhaf yönlerden" incelediğini belirtir. Filmlerinde sıradan insanların hikayelerine odaklanır. "Sabit kamera kullanımı, uzun planlar, arabaların içinde geçen yoğun diyaloglar, dramatik yapıdaki bazı unsurları göstermeyerek sözlü-sesli anlatımla vurgulaması gibi deneysel 
çalışmalarıyla Kiarostami, sinemanın anlatım olanaklarını zenginleştirmektedir." Kiarostami, sıradan öyküler anlatırken bile deneysel teknikler kullanarak, zengin bir anlatıma sahip filmler yapmıştır. (Torun, 2016: 116-119). Kiarostami, Nancy ile yaptığ1 ve Hayal Perdesi sinema dergisinde yayınlanan sohbetinde sinemada öykü anlatımı hakkında şunları söyler

\begin{abstract}
"Herhangi bir öykü anlattığımızda, aslında anlattığımız sadece tek bir öyküdür ve dinleyicilerinin her biri de, kendilerine has hayal güçleriyle, sadece tek bir öykü duyarlar. Fakat hiçbir şey söylemediğimiz zaman, sanki çok fazla şey söylemişiz gibi olur. Elinde gücü tutan izleyici olur (...) Öyküsel sinemaya tahammül edemiyorum. Salonu terk ediyorum. Öykü anlatmakla ne kadar meşgul olursa ve bu işi ne kadar iyi yaparsa, benim de ona karşı direncim o kadar güçleniyor. Yeni bir sinema tasavvur etmenin tek yolu izleyicinin rolünü daha fazla kâle almaktır. Bitmemiş ve tamamlanmamış bir sinema tasavvuru elzemdir, böylece izleyici müdahale edebilir ve boşluğu, eksiklikleri doldurabilir. Kesintisiz ve kusursuz yapısı olan bir film çekmektense, yönetmen yapıyı zayıflatmalıdır -ama izleyiciyi uzaklaştırmaması gerektiğini aklından çıarmadan!"
\end{abstract}

Kiarostami izleyicisine, bazı anlarda izlediklerinin bir film olduğunu hatırlatırken, bazen de bir film izlediklerini unutturmayı başarır ve kurmaca ile gerçeklik arasında şaşırtıcı bir denge kurar. Kiarostami, filmlerindeki yönetmen-oyuncu-seyirci arasındaki iktidar ilişkilerini de sorgulayan bir yönetmendir. Bu denkleme bakıldığında yönetmen ve oyuncu işin üretim tarafındayken seyirci ise tüketici konumundadır. Yönetmen kameranın arkasında, oyuncu kameranın önünde ve perdedeyken, seyirci de perdenin veya ekranın karşısında konumlanır. Yaygın kanıya göre film setinde yönetmen veya yıldız bir oyuncu otorite konumundadır ve çevresini kendisine göre şekillendirir. Seyirci ise edilgen bir durumdadır ve kendisine sunulanı izlemekle yükümlüdür. Kiarostami bu durumu tersine çevirir. Oyuncusu ve seyircisi üzerinde bir tahakküm kurmayı denemez ve onları kendisiyle eşit seviyede konumlandırır. Hatta daha da ileri giderek filmin yaratıcısının film bittikten sonra aradan çekilmesi gerektiğini ve kendi filmiyle ilgili yaptığı yorumların çok önemli olmadığını ve seyircinin de kendini filme katması gerektiğini savunur. Böylece bütün işi yönetmenin yapmasına da gerek kalmadığını belirtir. (Cronin, 2017: 28) Kiarostami, yönetmen olarak otoriter bir rol çizmez ve oyuncularını -dolayısıyla filmin akışını- kendi haline bırakır. Kiarostami 'ye göre bir yönetmenin yapacağ1 en kolay ve kötü iş oyunculara neyi yanlış yaptıklarını söylemek ve bu yolla kontrolü elinde tutmaktı. Her şeye müdahil olan bir yönetmen hem oyuncular için hem de set çalışanları için problem teşkil etmektedir ve bu durum da filmin doğallığı önünde büyük bir engeldir. Kiarostami, bu otoriter ilahi figürün gerçeklerle yüzleştirilmesi gerektiğini savunur ve geleneksel yönetmenlik anlayışına sırtını döndüğünü ve bu sayede oyunculara artan oranda imkanlar vermeyi denediğini belirtir (Cronin, 2017: 190-192).

\title{
Abbas Kiarostami'nin Dijital Sinemayla İlişkisi ve Kendini Görünmez Kılma Çabası
}

Abbas Kiarostami, ilk filmi 1974 yapımı Misafir'den 1999 yılında çektiği Rüzgar Bizi Sürükleyecek filmine kadar geçen yirmi beş yıllık süreçte analog sistemlerle çalışmıştır. Kiarostami, analog ve dijital film arasındaki farkı şu sözlerle ifade eder (Cronin, 2017: 44-45):

“Dijital kameranın ortaya çıkışı ve bu yeni kameraların sunduğu imkanlar filmi nasıl yapacağımıza dair büyük değiş̧iklikler getirdi ve bir nevi dileğim gerçekleşmiş oldu. Hafif dijital kameralar, oyuncularla aramdaki mesafeyi en aza indirdi. Etrafimız, koca koca ekipmanlar ve bir sürü insanla kuşatılmadığından aramızda samimiyet daha hızh bir şekilde oluşuyor. Yeni teknoloji, 
hakikaten hareket özgürlüğ̈̈ sağlıyor ve benim çalışma şeklime uyan imkanlar sunuyor. Yıllar boyunca kameraya yalnızca bir not alma aracı olarak baktım ancak kamerayı ciddiyetle kullanmaya başladığımda imkanları, özellikle de nihayet hakikatin hakkını verebileceğimi anlamaya başladım. 35 milimetre ile çekim yaptığım yılları boşa harcamışım gibi hissettim."

Abbas Kiarostami ilk kez Kirazın Tadı filminin son bölümünde dijital kamerayla çekilen görüntüleri kullanmıştır. Bunun sebebi $35 \mathrm{~mm}$ olarak çekilen filmin son bölümünün laboratuvarda bozulması ve aynı sahneleri baştan çekmenin mümkün olmamasıdır (DönmezColin, 2012: 71). Yönetmenin tamamı dijital ilk filmi Uganda'daki AIDS salgınını konu aldığ1 ABC Africa (ABC Afrika, 2001) isimli belgeseldir. Kiarostami, bu filmin yapım hikâyesini şu sözlerle anlatır:

\footnotetext{
"Planımız gidip çekim yapmak ardından yapımcı bulmak ve daha büyük kameralarla geri dönmekti ancak anlık yaptığımız çekimler o kadar heyecan vericiydi ki geri dönmenin bir anlamının olmadığını fark ettik. Bu ham malzemelerde, faydalı bir şekilde detaylandırabileceğimizi düşündü̈̆̈̈müz bir şey yoktu. ABC Afrika'nın gücü, görüntülerde herhangi bir dayatmanın olmamasındadır. El kameralarımı 360 derece dönebildiğinden mutlak hakikati her bir açıdan kaydetmişti. Böylesine nefes kesici bir canlllikla dolu bir malzeme, keşfin ve araştırmanın özgün hali, filmi çekerken asla benzerinin elde edilemeyeceğini düşündüğüm görüntüler..." (Cronin, 2017: 200)
}

Kiarostami, Afrika'ya deneme çekimi için gitmesine rağmen dijital kameradan oldukça memnun kalır ve deneme çekimleri bir anda gerçek çekimlere dönüşür. Kiarostami bu noktada kendine şunu sorar "O halde neden 35 mmlik bir kameraya geri dönelim ki?" (Cronin, 2017:200). ABC Afrika filminden bir yıl sonra ise Kiarostami yine dijital kameralarla Ten (On, 2002) filmini çeker. Bu film hakkında şunları söylemiştir: “On filminde, kısmen arabanın sınırlı mekanından ötürü, yönetmen olarak tüm gücümden neredeyse feragat ettim ve gereksiz müdahalelerden kaçındım. Serbest bırakıldıklarında akışın kendiliğinden gerçekleşmesi ve etkileyici olması karşısındaki şaşkınlığımdan ötürü tüm yaptığım gözlemlemek ve sevgiyle muamele etmekti." der (Cronin, 2017: 190) On filminden sonra Kiarostami Five (Beş, 2003) isimli başka bir dijital film çeker. Kiarostami bu filmi hiçbir teknisyenden destek almadan tek başına çekmiştir. (Dönmez-Colin, 2012: 72). Film 15-20 dakika aralığında değişen beş epizottan oluşmaktadır. Diyalogsuz ve ağır ilerleyen, pastoral bir filmdir.

Kiarostami'nin eski asistanlarından ve İran'ın önemli yönetmenlerinden Cafer Panahi, "Film çekerken çoğu zaman o kadar dalıyoruz ki, film çektiğimizi unutuyoruz. Gerçeğin peşindeyiz. Gerçekle bu yakınlaşma çabası, sonuca da yansıyor, sorunlar gerçek, karakterler gerçek, çıkış noktamız gerçek, film ekibi olabildiğince müdahale etmemeye çalışıyor". (Atam, 2005) derken Asghar Farhadi ise "Batı sanatında sanatçı kendini göstermeye çalışır. Doğu sanatında ise sanatçı kaybolmaya çalışır. Batı sanatındaki bir eseri değerlendirirken, imzadan ayrı düşünemezsiniz. Doğu'da böyle değildir. Sanatçı aradan çıkar." ifadeleriyle kendi bakış açılarından yönetmenin bir filmde kendini görünmez kılma çabası hakkında görüşlerini belirtmektedirler. (Farhadi, 2016). Panahi, filmde müdahalesiz bir şekilde çekim yapıldığını vurgularken, Farhadi ise duruma kültürel bir perspektiften bakarak Doğu ve Batı kültürlerinde sanatçının varlığını kıyaslar ve Doğu kültürlerinde sanatçıların kendini gizleme arzusunda olduğu tespitinde bulunur.

Kiarostami eserin içine kendini gizlemeyi iki farklı düzlemde gerçekleştirmiştir. Yönetmen ilk olarak kendini, filmin çekim aşamasında özellikle de film setinde oyunculara 
mümkün olduğunca müdahale etmeyerek ve onları serbest bırakarak gizlerken, ikinci olarak filmin seyirciyle kurduğu etkileşim noktasında kendini gizlemektedir. Kiarostami sette oyuncuyu, film izlerken de seyircisini özgürleştiren bir yönetmendir. Bu noktada Ranciere, seyirci-film arasındaki ilişkinin izleyiciyi edilgen kıldığını ve buna sebep olan 'ukala' mesafenin ortadan kalkması gerektiğini savunur. Kiarostami'nin filmleri ise Ranciere'in görüsslerini destekler niteliktedir:

“Bakmak bilmenin zıddıdır. Seyirci bir görünüşün karşısına geçer, ama o görünüşün üretim sürecini veya gizlediği gerçekliği bilmez. İkinci olarak bakmak, eylemenin zıddıdır. Edilgen olan seyirci yerinde olduğu gibi hareketsiz durur. Seyirci olmak, hem bilmek kabiliyetinden hem de eylemek kudretinden kopmak demektir. Bu ukala mesafenin kendisi ortadan kaldirlmalıdır. Seyirci, kendisine sunulan gösteriyi sükûnet içinde inceleyen gözlemci konumundan çıkarılmalıdır. (Ranciere, 2010)

Kiarostami'nin filmde kendini görünmez kılma arzusunun en somut örneği olarak Ten filmi hakkında söyledikleri örnek verilebilir. Yönetmen filmin bazı sahnelerinde filmin çekimlerinde bile bulunmamıştır. Kiarostami 2005 yılında The Guardian'da² verdiği bir röportajda tamamı araba içinde geçen Ten filminin çekimiyle ilgili şunları söyler:

"Ten filmini çekerken bazen arka koltukta oturmayı tercih ediyordum, hemen hemen hiç müdahale etmedim. Hatta bazen arkadaki arabayla takip ettiğim için 'sete' bile katılmadım. Bensiz daha rahat oldukların düşünüyordum. Yönetmenler her zaman yaratmazlar bazen sürekli talepte bulunarak yıkıcı da olabilirler. Amatör oyuncu kullanmanın bazı kuralları vardır. Onlara kendilerini istedikleri gibi ifade etmelerine izin vermelisiniz."

Kiarostami Ten filmi için " bir süredir yapmaya çalıştığım işe bir adım daha yaklaşmış oldum: Yönetmenin elini çekmesi ve sıradan sinemanın üzerine kurulu olduğu belli başlı unsurların reddi" şeklinde yorum yapar. Kiarostami, Ten filminin çekimleri sırasındaki düşüncelerini şu sözlerle ifade eder (Colin-Dönmez, 2012: 71-72):

“Insanların küçük bir kameranın önünde çok rahat oldukların fark ettim. Çekim yaptı̆̆ım otuz yıl boyunca, sürekli insanları rahatlatmaya çalıştım. Gerçek mekânlarda gerçek insanlarla çalıştım; ancak kocaman kameralar yüzünden profesyonel olmayanlarla çalışmak oldukça güçtü" (...) "Dijital kamera sayesinde profesyonel olmayan oyuncular kullanabildim. On'u bitirdiğimde film yapmak için gerekli olan en iyi kamera sonunda icat edildi diye düşünmüş̧üm. Bu kamerayla insan mahrem anları, örneğin anne oğul arasında geçen diyaloğu kaydedebiliyor."

Abbas Kiarostami'nin röportajlarında ifade ettiklerine, filmlerini yapma biçimlerine ve uyguladığı tekniklere bakıldığında eserlerinde kendi varlığını minimum seviyede tutma çabası içinde olduğunu söylemek mümkündür. Bu durum yönetmenin kendi varlığını filmin içinde kaybetme veya başka bir deyişle yönetmenin kendi varlığını filmin içinde eriterek filmle bütünleşmesi olarak ifade edilebilir. Dijital teknolojiler onun bu arzusunu karşılama noktasında çok önemli bir işleve sahiptir. Dijital teknolojilerin bir diğer avantajı da analog sistemlere göre daha 'akıllı' ve kontrol edilmesi kolay olduğu için daha az sayıda insana ihtiyaç duyulmasıdır. Dijital teknolojilerin yönetmene sınırsız seçenek sunması ve film yapım maliyetinin azalmasıyla risklerin daha kolay alınması, film ekipmanlarının küçülmesi ve buna bağlı olarak filmde çalışan kişi sayısının azalması gibi nedenlerle yönetmenler analog döneme göre daha büyük bir özgürlük ve hareket alanına sahip olmuştur. Her zaman yenilikçi ve farklı

2 https://www.theguardian.com/film/2005/apr/28/hayfilmfestival2005.guardianhayfestival (Erişim Tarihi: 10.10 .2018 ) 
bir bakış açısıyla film yapan Kiarostami dijital teknolojinin imkânlarını kullandığı Ten ve Şirin gibi uzun metrajlı filmlerinde de kendine özgün bir sinematografik üslup geliştirmiştir. Bu doğrultuda Kiarostami'nin dijital sinema teknolojilerini kullanarak çektiği Ten ve Şirin filmleri hikaye, oyunculuk, görüntü düzenlemesi/çerçeveleme, kurgu teknikleri ve filmde kullanılan mekanlar bağlamında incelenecek ve Abbas Kiarostami'nin filmleri üzerine röportajlarında yer verdiği söylemler doğrultusunda yönetmenin kendini bir filmde nasıl görünmez kıldığı değerlendirilecektir.

\section{Ten ve Şirin Filmleri}

Ten filmi İran' da bir kadın şoförün araba yolculuğundan on farklı zaman dilimindeki kesitlerden oluşur. Film bir erkek çocuğun arabanın ön koltuğuna binme görüntüsüyle açılır. Çocuk arabaya binince araba hareket eder ve arabayı süren kişinin çocuğun annesi olduğu diyaloglardan anlaşılır. Yaklaşık 16 dakika boyunca hareket halindeki arabada sadece çocuğu görürüz. Anneyi ise sadece işitiriz. Arabaya binen her bir insanın farklı hikâyesi, farklı dertleri veya beklentileri vardır. İzleyici olarak biz bunlara üçüncü bir göz olarak şahit oluruz. Film boyunca şoför koltuğundaki kadın sabit kalıp yanındaki kişi değişse de kadınla da bir özdeşim söz konusu değildir. Film herhangi bir karakterin bakış açısını yansıtmaz. İzleyici tamamıyla olayları dışarıdan gözlemleyen bir konumdadır. Arabaya kimin bineceğine dair hiçbir ipucu yoktur. Bu durum, rastlantısallık duygusu vererek filmin daha gerçekçi bir hal almasını sağlar.

Görüntü film boyunca sabittir ve filmde kullanılan açı sayısı sadece üçtür. Sanki yönetmen kamerayı arabaya yerleştirip gitmiştir ve film kendi kendine çekiliyormuş gibidir ki Kiarostami'nin açılamalarına bakıldığında durumun biraz da böyle olduğunu söylemek mümkündür. Kamera hiçbir zaman arabanın içinden çıkmaz. Film sürekli aynı görüntüyü tekrar tekrar sunar. Kiarostami, çocuk veya annenin ruh hallerine uygun ölçekler kullanmamış ve bu şekilde dramatik bir etki yaratma yoluna gitmemiştir.

$\mathrm{Bu}$ durum filmin kurgusunu da doğrudan etkiler. Filmin kurgusu, zamansal olarak sadece ileri doğru akar. İleri veya geri doğru büyük zamansal sıçramalar yoktur. Kesitler birbirinden siyah ekrana yazılan beyaz rakamlarla ayrılır. Bu görsel aynı zamanda hepimizin aşina olduğu, bir film başlarken 10'dan geriye doğru sayımı hatırlatmaktadır. Ayrıca filmde müzik de kullanılmaz.

Oyunculuklar ise son derece doğaldır. Hatta neredeyse bir oyunculuktan söz edilemez. Filmdeki kişiler elbette bir filmde olduklarının farkındadır. Ancak filmde klaket kullanılmaması, kalabalık bir ekibin yer almaması ve filmin yönetmeninin kendilerine neredeyse hiç müdahalede bulunmaması oyuncuların rahat ve doğal olmasını sağlamıştır. Kiarostami zaten hiçbir filminde oyunculara bir metin ezberletmediğini, oyuncuların duruma uygun cümleleri kendilerinin içinden geldiği gibi ifade ettiğini belirtmektedir. Bu filmde de aynı durum geçerlidir. Kiarostami burada kendini izleyiciden değil, oyuncudan da gizler demek mümkündür. “Ten filmi ile ilgili hiçbir şey yapmadı̆̆ıma dair bir düşünce var. Yalnızca herkesi bir arabanın içine yerleştirdim ve bütün sorumluluğu onlara verdim." (Cronin, 2017: 190).

Filmdeki mekan kullanımlarına baktığımızda mekan olarak yalnızca bir arabanın kullanıldığını düşünülebilir fakat buna farklı açıdan bakarsak arabanın sürekli hareket halinde olması filmin mekanını da genişletir. Filmin görünen mekanı belki bir arabadır ama algılanan mekan Tahran'ın bütün sokaklarıdır. İzleyici sadece arabanın içini görse de dışında bir hayatın varlığını da hissetmektedir. İzleyicinin bakışı sınırlı gözükse de bu sınırlılık ona daha zengin bir 
dünya sunar. Anne çocuğunu yüzme havuzuna ve daha sonra büyükannesinin evine bırakır, arabasına binen yaşlı bir kadını onun ricası üzerine bir türbeye bırakır. Filmin mekanının arabayla sınırlı olmadığını söylemek mümkündür. Bu durumu da yönetmenin dijital teknoloji sayesinde giremeyeceği yerlere artık girebilmesi şeklinde yorumlanabilir.

Şirin filmi ise bir sinema salonunda Hüsrev ve Şirin efsanesinin filmini izleyen 113 kadının yakın plan çekimlerinden oluşur. Şirin fimi bir sinema salonundaki kadın seyircilerin film izleme deneyimlerine odaklanır fakat kadınların izledikleri filmi hiçbir zaman görmeyiz. Sadece işitiriz. İzleyici olarak gördüğümüz tek şey film izleyen kadınların yüzleri ve filme verdikleri tepkilerdir. Filmi izleyen bu kadınlar, nerede yaşarlar? Ne yerler, ne içerler? Hayattaki amaçları nedir? Buna benzer onlarca soru cevapsızdır ve film bununla ilgilenmez. Bunun yerine hiç göremediğimiz Hüsrev, Şirin ve Ferhat'a dair daha çok bilgi ediniriz. Kiarostami bu filmin yapım öyküsünü şu sözlerle anlatır (Cronin, 2017: 207-207):

“Bütün çekimler Tahran'daki evimin bodrum katında yapıldı ve kadınların hiçbiri de herhangi bir şey izlemiyordu. Her biri profesyonel olan kadın oyunculara, önlerindeki tripodun üzerinde duran üstüne üç tane çizgi çizdiğim beyaz kâğıda birkaç dakika boyunca bakmalarını söylemek dışında bir yönlendirme yapmadım. (...) Her şey doğaçlamaydı. Oyuncular, sandalyelerine oturmalarından otuz saniye öncesine kadar hiçbir şey bilmiyordu. Zaman zaman aralarından bazılarına oturduğu yerde kıpırdanmasını, gözlerini silmesini ya da başörtüsünü düzeltmesini söyledim, ara ara da eğlenceli bir şeyler izliyormuş gibi davranmalarını önerdim. Odanın arkasında otururken oyuncular ürkütmek için ara sıra metal bir tepsiyi yere düşürdüm.(...)Çektiğim onca saatlik görüntülerin üzerinden geçtim, yalnızca uygun olduğunu düşündüğüm anlar seçtim ve bu sahneleri ses kaydryla eşleştirdim. Oyunculardan herhangi birinin tepkisinin hikâyede olanlarla bağdaştı̆̆ı durumlarda görüntüleri kullandım. Her bir sahne için görüntüleri nihai haline ulaşana dek durmaksızın değiştirip durdum. Yeni bir filmi ortaya çıkarmak için bu yüzlerce dakikalık görüntüyü bir araya getirmenin neredeyse sonsuz yolu vardır. Görüntülerin kurgusu beş aydan fazla sürdü. Belli bir noktada kendimi durmaya zorladım."

Kiarostami'nin film hakkında söylediklerine bakıldığında çok küçük birkaç müdahele dışında oyuncularını yönlendirmediği görülmektedir. Filmsel mekan sinema salonu olsa da film bir bodrum katında çekilmiştir. Çekimler doğaçlama bir şekilde ilerlemiştir ve filmin asıl anlamı artık 'sonsuz' seçenek imkanı sunan kurguda ortaya çıkmıştır. Film şu sözlerle başlar.

"Dinleyin beni kardeşlerim. Size kendi hikâyemi anlatacağım. Tam burada... Hüsrev'in cansiz bedeninin yanında."

Filmin ilk cümlesinin "Dinleyin beni kardeşlerim" olması filmin izleyicisine gözlerinden ziyade kulaklarına daha fazla ihtiyaç duyacağının ipuçlarını vermektedir. Bu diyalogdan bir süre sonra ise Şirin arkadaşlarıyla körebe oynamaktadır ve Şirin'in arkadaşlarından birisi şunları söyler:

"Gözlerin bağhl; kulaklarını dört aç! Sesimizi izle!"

Filmin sonlarına doğru Hüsrev ile Şirin arasında şu konuşmalar geçer:

"Kimdir bana seslenen?

-Telaşlanma sevgilim. Benim; Şirin.

Göremiyorum seni, Şirin.

Bu karanlıkta gözlere ihtiyacın yok. Ellerimi tut, saçımı okşa. Kalbimin atışını duyabiliyor musun?" 
Filmde yer verilen bu üç diyalog da filmin göze değil kulağa hitap ettiğini vurgular niteliktedir. Körebe oyununun oynanması da bir metafor olarak düşünülebilir. Kiarostami de, Şirin filminde izleyicisiyle bir anlamda körebe oynamaktadır. Şirin filmi, -gözleri bağlı- izleyicinin sadece seslerle yolunu bulabileceği bir film evreninde geçmektedir.

$\mathrm{Bu}$ nedenle filmde tıpkı Ten filminde olduğu gibi Şirin filmi de benzer görüntülerin sonsuz döngüsünden oluşmaktadır. Bu görüntü film izleyen kadın seyircilerin görüntüsüdür. Hep ayn plan ve ayn ölçek tercih edilir değişen sadece filmin kadın izleyicileridir. Onların izledikleri filme verdikleri tepkiler filmin odak noktasını oluşturur.

Film zamansal açıdan bakıldığında sürekli ileri doğru akar. Zamanda ileri veya geriye sıçramalara yer verilmez. Bu zaman kullanımı filmin kurgu stiline de yansımaktadır. Kurgusal olarak sadece kesme geçişlere yer verilir. Şirin filmi, kadın seyircilerin filmi izlemeye başlamasıyla başlar, izledikleri filmin bitmesiyle sona erer. Film süre olarak da bir buçuk saatlik zaman dilimini kapsar yani gerçek zamanlıdır.

Oyuncular ise sadece gördükleri ve işittikleri karşısında tepki verirler. Film izledikleri için aralarında hiçbir diyalog olmaz. Filmde olay örgüsü de söz konusu değildir. Kadınların sinemaya girişi, sinemadan çıkışı gibi sekanslar eklense bir olay örgüsünden bahsedebilirdik ama film, filmin içindeki filmin başlamasıyla başlar, filmin içindeki filmin bitmesiyle sona erer. Filmin görünen mekanı sadece bir sinema salonu olsa da kadın seyircilerin izledikleri filmin mekanları arasında zihinsel bir yolculuğa çıarız. Filmin sonunda kredi akarken de oyuncular yerine izleyiciler yazmaktadır. $\mathrm{Bu}$ da tesadüfi bir durum değildir. Kiarostami izleyen-izlenen ilişkisini ters düz eder. Klasik sinemada bir izleyen bir de izlenen varken Şirin filminde izleyici başka bir izleyici izler. Yani artık izlenen de izlenmektedir. İzleyen ve izlenen arasındaki mesafe ortadan kalkmaktadır.

\section{Sonuç}

Dijitalleşmeilebirliktetümalanlardaolduğugibisinemadadabüyükbirdönüşüm yaşanmaktadır. Analog ve dijital film yapımı kıyaslandığında, dijital teknolojilerin film yapımının bütün aşamalarında önemli avantajlar getirdiği görülmektedir. Bu avantajlar sadece maliyetlerin düşmesi, ekipmanların küçülmesi, genç sinemacıların önünün açılması, görsel efektler, sanal gerçeklik vb. ile sınırlı değildir. Dijital teknolojilerin yaygınlaşmasının bir sonucu olarak film yapım pratikleri değişmeye başlamıştır. $\mathrm{Bu}$ değişimin doğal bir sonucu olarak film yönetmenleri, dijital sistemleri kendi felsefeleri ve üretim anlayışları doğrultusunda kullanma eğilimindedirler. Dijitalleşmeyle doğrudan bir ilişkisi yokmuş gibi görünse de minimal, şiirsel ve doğal bir stile sahip Abbas Kiarostami de dijital sistemleri oldukça yaratıcı biçimde kullanan ve bu konuda öncü yönetmenlerden biridir. Film ekipmanlarının ucuzlaması ve küçülmesinin de etkisiyle Kiarostami sinemasında film evreni ile gerçek hayat arasındaki sınırlar da birbirine gittikçe yakınlaşmakta hatta ayırt edilemeyecek noktaya gelerek iç içe geçmektedir. Kurmaca ve gerçeklik arasındaki sınırların bu denli muğlaklaşması da izleyici-oyuncu ve yönetmen arasındaki sınırları da büyük ölçüde yok eder. Kiarostami, dijital sinema ekipmanlarını kullanarak bir yönetmen olarak kendini görünmez 
kılar. Çalışmanın başında da yer verilen Kiarostami'nin "Filmlerimin bazılarında yönetmen olarak ne yaptığım sorulacak olsa 'Hiçbir şey. Ama yine de ben olmadan var olamazlardı' derim." sözünü hatırlatmakta fayda vardır (Cronin, 2017: 191). Bu sözden yola çıkarak Kiarostami' nin bu durumun farkında olduğunu ve bunu bilinçli olarak yaptığını söylemek mümkündür. Çalışmada analiz edilen iki filme bakıldığında; filmlerin sanki bir yönetmen elinden çıkmamış, kendiliğinden kaydedilen doğallıkta olduğu görülmektedir. İki filmde de kamera, kurgu, oyunculuk, mekân kullanımı bu kesintisiz gerçekliği bozmayacak şekilde kullanılmıştır. Filmlerde gizli bir kamera kayda girmiş ve kesintisiz bir hayat devam ediyor gibidir. Yönetmenin tercihlerine bakıldığında karakterlerin ruh hallerinin değişimine veya bedensel hareketlerine göre kamera hareketine veya farklı bir ölçek kullanımına yer verilmemiştir. Görüntü sürekli kendini tekrarlamaktadır. Kurgu zamansal olarak gerçek hayatta olduğu gibi ileriye doğru akar ve ileri ve geriye doğru büyük zamansal sıçramalar yer almaz. İki filmde de tek mekân kullanılırken, müzik kullanılmaz. İçerik açısından da tercih edilen konular oldukça minimaldir ve karmaşık değildir. İzleyici, Ten filminde karakterlere dair bilgiyi diyaloglar yoluyla öğrenirken, Şirin filminde görünen bir karakterden bile söz etmek güçtür. İki filmde de sinematografik ve içerik açısından filmsel öğeler minimum seviyede kullanılmaya çalışılmıştır. Yönetmen ve izleyici ilişkisi açısından bakıldığında ise iki filmde de izleyen ile izlenen arasındaki sınırları kaldırma çabası yönetmenin kendini filmde gizlemesiyle gerçekleşir. İzleyici ile izlenen arasında net bir ayrımın oluşması yönetmenin varlığına bağlıdır. Yönetmen, izleyici ve izlenen arasından çekilip onlarla bütünleşirse sinemanın gerçeklikle olan ilişkisi de yeni bir boyut kazanacaktır. Böyle bir durumda izleyiciler bir film izlediğinin hem farkındadır hem de değildir. Ten ve Şirin filmlerinde de Kiarostami'nin varlığı bilinir ve hissedilir fakat kendisi görünmezdir. İki filmde de oyunculuklar teatral değildir, kapalı mekanlar tercih edilir ve tek mekan kullanılır, görüntüler sadedir, zamansal sıçramalara rastlanmaz, kurgusal geçişlerden büyük oranda kaçınılır. Kiarostami, filminin oyuncusu ve izleyicisi üzerinde bir otorite kurmaz. Kendisini, filmlerinde yer alan oyuncularla ve filmlerinin izleyicileriyle ayn seviyede konumlandırır ve hem oyuncularını hem de izleyicilerini yönlendirmekten kaçınır. Çünkü yönlendirme yaptığı sürece varlı̆̆1 hissedilecek ve görünmezliğini kaybetme tehlikesiyle karşı karşıya kalacaktır.

\section{Kaynakça}

Aktaş, C. (2015). Şark'ın Şiiri: İran Sineması, İstanbul: İz Yayıncılık.

Atam, Zahit (2005), “Ne Kadar Güçlü Olursan Ol, İnsanın Özgürlügü İçin Bir Çözüm Bulmalısı", Cafer Panahi ile Söyleşi, Yeni İnsan Yeni Sinema Dergisi, Sayı: 16: 146-152

Aytaçlı, B. (2012). Durum çalışmasına ayrıntılı bir bakış. Adnan Menderes Üniversitesi Eğitim Fakültesi Eğitim Bilimleri Dergisi, 3(1), 1-9.

Bergan, R. (2008). Film, Zeynep Berik (çev.), İstanbul: İnkilap

Cronin, Paul (2017), “Abbas Kiyarüstemi ile Sinema Dersleri” (Çev. Pelin Arda), Redingot Kitap, İstanbul

Dabaşi, H. (2013). İran Sineması. Çev. B. Aladağ/ B. Kovulmaz Agora kitaplığı, İstanbul.

Dönmez-Colin, G. (2012). Öteki'nin sinemaları: Ortadoğu ve Orta Asya sinemalarında kişisel bir yolculuk. Agora Kitaplığı. (Çev. Jefroudi, M.) 

Yayınları.

Elsaesser, T., \& Hagener, M. (2014). Film kuramı: duyular yoluyla bir giriş. Dipnot

Erkılıç, H. (2018). Dijital Sinema Teorisi Üzerine: Akışkan Sinema ve Akışkan Sinema Teorisi. SineFilozofi, 2(4).

Kıraç, Rıza (2000), “Şiddet, Oryantalizm ve Minimalizm-90’lı Yıllarda Türk Sinemasına Genel Bir Bakış-Bölüm 2", 25. Kare, Sayı:31: 11-17.

Kırel, S. (2007). “İran'da Sinema: İran Sineması ve Üretim Dinamikleri ve Anlatıya Etkileri Üzerine Bir Değerlendirme. Üçüncü Sinema ve Üçüncü Dünya Sineması, Es Yayınları, İstanbul.

Köprü, M. (2009). Bazin' in Dijital Kameraları, Eisenstein'ın Bilgisayar EfektlerineKarşı: Geleneksel Kuramların Bakışıyla Yeni Film Teknolojiler. İletişim Araştırmaları. Cilt:7, Sayı:12, ss. 49-77

Monaco, J. (2011). Bir film nasıl okunur?: sinema dili, tarihi ve kuramı: sinema, medya ve multimedya dünyası. Oğlak Yayıncılık.

Nafisi, H. (2008). “İran Sineması” Dünya Sinema Tarihi Ed. Geoffrey Nowell-Smith, (Çev. A. Fethi), , Kabalcı Yayınları, İstanbul, 772-766.

Nişanc1, İ. (2011). Kurgunun Güncel Sorunsalı: Eisenstein'ın Dikey Kurgusunun Evrimi. İletişim Fakültesi Dergisi, Sayı:41, ss.63-80.

Ormanl, O. (2014). Dijitalleşme Ve Türk Sinemas1. The Turkish Online Journal of Design Art and Communication, 2 (2), 32-38. Retrieved from http:/ / dergipark.gov.tr/tojdac/ issue/13009/156739 Konumu.

Öztaş, P. (2012). Pelikülden Dijitale Sinemada Seyir Kültürü ve Seyircinin Değişen

Parsa, Alev, Akçora, Elçin (2016). “Dijital sinemada yeni anlatım formları: Görsel Efektler". 1. Uluslararası Görsel Sanatlar ve Estetik Sempozyumu, pp: 219-240.

Ranciere, J. (2010). Özgürleşen Seyirci, çev. E. Burak Şaman, İstanbul: Metis.

Teksoy, R. (2005). Dünya Sinema Tarihi. İstanbul, Oğlak Yayınları.Torun, A. (2015)

Usai, P.C (2008). “İran Sineması” Dünya Sinema Tarihi Ed. Geoffrey Nowell-Smith, (Çev. A. Fethi), , Kabalcı Yayınları, İstanbul, 22-30.

Filmler

Şirin (2008), Yön. Abbas Kiarostami, Oyn. Mahnaz Afshar, Pegah Ahangarani, Taraneh Alidoosti, vd.

Ten (2002), Yön. Abbas Kiarostami, Oyn. Mania Akbari, Amin Maher, Kamran Adl vd. İnternet Kaynakları

https:/ / www.theguardian.com/film/2005/apr/28/hayfilmfestival2005. guardianhayfestival (Erişim Tarihi: 10.10.2018)

http:/ / www.cinerituel.com/2016/10/asghar-farhadi-master-class-konusmasi-tammetin.html (Erişim Tarihi: 18.10.2018) 